\title{
Effects of Ethical Climate on Organizational Commitment, Professional Commitment, and Job Satisfaction of Auditor in Malaysia
}

\author{
Suhaiza Ismail \\ Kulliyyah of Economics and Management Sciences, Intemational Islamic University Malaysia, Malaysia
}

\begin{abstract}
The objective of this paper is to investigate the effect of the ethical climate on the organizational commitment, professional commitment and job satisfaction of Malaysian auditors. Using a survey questionnaire comprising instruments about the ethical climate, organizational commitment, professional commitment and job satisfaction, 263 usable responses were received. To achieve the objectives, mean scores, standard deviations, correlations and multiple regressions were performed. The study revealed that a significant positive influence of a caring ethical climate on professional and organizational commitment as well as job satisfaction existed. There was also a positive significant association between the law and code ethical climate and professional commitment. On the other hand, the study discovered that the instrumental ethical climate type had a significant negative relationship with organizational commitment and job satisfaction. A significant negative relationship was also revealed between the independent ethical climate type and organizational and professional commitment. A significant negative relationship between the rules ethical climate and job satisfaction was also discovered.
\end{abstract}

\begin{abstract}
Abstrak: Tujuan dari penelitian ini adalah untuk meneliti efek dari iklim etika pada komitmen organisasi, komitmen profesional dan kepuasan kerja auditor Malaysia. Survei kuesioner yang terdiri dari instrumen pada iklim etika, komitmen organisasi, komitmen profesional dan kepuasan kerja digunakan dalam penelitian ini dan terdapat 263 tanggapan yang dapat digunakan. Untuk mencapai tujuan penelitian, dilakukan uji skor rerata, standar deviasi, korelasi dan regresi berganda. Hasil penelitian mengungkapkan ada pengaruh positif yang signifikan dari iklim etika yang peduli terhadap komitmen profesional dan organisasional sebagaimana juga dengan kepuasan kerja. Selain itu terdapat juga asosiasi positif yang signifikan antara hukum dan iklim kode etika dengan komitmen profesional. Di sisi lain, dalam penelitian ini ditemukan bahwa jenis iklim etika instrumental memiliki hubungan negatif yang signifikan terhadap komitmen organisasi dan kepuasan kerja. Hubungan negatif yang signifikan ini juga ditunjukkan melalui jenis iklim etika bebas dengan komitmen organisasional serta profesional. Hubungan negatif yang signifikan antara peraturan iklim etika dengan kepuasan kerja juga ditemukan dari hasil penelitian ini.
\end{abstract}

Keywords: auditors; ethical climate; job satisfaction; Malaysia; organizational commitment; professional commitment

JEL classification: M40

* Corresponding author's e-mail: suhaiza@iium.edu.my 


\section{Introduction}

Malaysia is expected to become a highincome status nation by the year 2020. In facilitating the achievement of the government's goal, the auditing profession is directly affected, as it needs to greatly increase the number of auditors in line with the significant growth of the Malaysian economy (The Star 2013). According to the President of the Malaysian Institute of Accountants (MIA), Mr Johari Idris, the MIA is targeting an increase in the number of professional accountants in Malaysia from the current 30,000 to 60,000 within the next six years (The Star 2013; and The New Straits Times 2014). For the auditing profession in Malaysia, therefore, this, presents the formidable challenge of doubling the number of its members within the next few years.

In relation to the growth of the professional membership, studies by Cotton and Tuttle (1986) and PwC Malaysia (2013) have both discovered that work-related factors including the organizational climate, job satisfaction, work commitment and organizational commitment are important to the recruitment and retention of auditors. In light of the challenge that is facing the auditing profession and the vital role of work-related factors, it is timely to undertake a study to understand better the professional context. In particular, the current study investigates the influence of the ethical climate on three work-related outcomes: organizational commitment, professional commitment and job satisfaction.

The ethical climate has a significant influence on the attitudes and behaviour of employees of an organization. Empirical findings, which have been mostly conducted in Western countries, discovered connections between the ethical climate and various types of work outcomes, such as job satisfaction, professional commitment and organizational commitment. However, as Hofstede's dimensions of cultural differences (Hofstede 1980) explained, countries like Malaysia have a culture which is different from that of developed countries such as the United Kingdom and the United States, and specifically where individualism versus collectivism and power distance are concerned. Unlike the United Kingdom and the United States, which have an individualistic culture, Malaysia has a collectivist culture whereby strong, harmonious connections between people in the community are valued (Hofstede 1980). Likewise, the difference in the culture in terms of power distance between Malaysia and the developed countries is also obvious. Essentially, Malaysia has a greater level of power distance than the United Kingdom and the United States. This greater power distance means that less powerful members of organizations are more accepted, and expect that power is distributed unequally (Hofstede 1980). In the context of an organization, subordinates acknowledge the power of others simply based on where they are situated in certain formal, hierarchical positions. In other words, the power distance does not reflect an objective difference in power distribution but rather the way people perceive the power differences (Hofstede 1980). Both collectivism and high power distance are important values for people in the Asian countries including Malaysia. Therefore, it is reasonable to suggest that such cultural differences between developed and developing countries may result in differences in the findings on the relationship between ethical climate types and work related outcomes. With this in mind, this study intends to contribute to the limited empirical evidence on the influences of ethical climate on several work-related outcomes in the context of a developing country, in this case Malaysia. 
The remaining part of this study is structured as follows. The following section reviews the relevant literature on the ethical climate, organizational and professional commitment and job satisfaction, and proposes hypotheses for the study. Then the next section describes the research methodology and procedures used in undertaking this study. Following this, the findings and results are discussed. The study concludes by identifying the implications and limitations of the study, in addition to offering suggestions for future studies.

\section{Literature Review and Hypotheses Development}

\section{Ethical Climate}

The organizational ethical climate refers to an organization's 'shared perceptions of what is ethically correct behaviour and how ethical issues should be handled' (Victor and Cullen (1987: 51-52). Ethical climate theory was originally formulated as a descriptive map of ethical decision making and actions within an organization, based on philosophical and sociological theory (Martin and Cullen 2006). Victor and Cullen $(1987,1988)$ proposed a theoretical typology of ethical climates comprising nine ethical climate types based on two categorical dimensions, each with three levels. The first dimension concerns the criteria used for making ethical decisions based on three major theoretical classes: egoism, benevolence and principles (Victor and Cullen 1987, 1988). Based on these three theoretical classes, three common possible positions to take when making ethical decisions are maximizing self-interest (egoism), maximizing mutual or joint interests (benevolence) and complying with deonto-logical standards (principles). The second dimension refers to the locus-of-analysis, that is the individual, local and cosmopolitan levels from which an analysis may be made. The combination of the items from the two dimensions enables a $3 \times 3$ matrix of ethical climate types, as shown in Figure 1.

In measuring the types of ethical climates within the organization, an Ethical Climate questionnaire was developed by Victor and Cullen $(1987,1988)$. From among the numerous studies that have adopted this measure, it could be concluded that not all organizations produce distinct climate types (Martin and Cullen 2006; and Shafer 2008). From an empirical application of this instrument, Victor and Cullen (1987) found five distinct types of ethical climate: the law and code climate (people are expected to comply with the law and professional standards), the caring climate (the major consideration is what is best for everyone in the organization), the rules climate (everyone is expected to conform to organizational rules and procedures), the instrumental climate (people protect their own interest above all else), and the independent climate (each person in the firm decides for him/herself what is right and wrong). The instrumental climate emerges from a combination of 'egoism/individual' and 'egoism/local' climate types; the caring climate is derived from a combination of 'benevolent/individual' and 'benevolent/local;' and the remaining three types (i.e. professionalism, independent and rules) are the three distinct climates at the principle level. Figure 2 illustrates the five types of ethical climate.

These five types of ethical climate derived by Victor and Cullen (1987) are commonly used in research into organizational studies. Among their applications, they serve as an instrument to measure how ethical climates affect a range of various organizational 
Figure 1. Theoretical Typology of Ethical Climate

Locus of Analysis

Ethical Theory

\begin{tabular}{|c|c|c|c|}
\hline & Individual & Local & Cosmopolitan \\
\hline Egoism & Self-Interest & Company Profit & Efficiency \\
\hline Benevolence & Friendship & TeamInterest & $\begin{array}{c}\text { Social } \\
\text { Responsibility }\end{array}$ \\
\hline Principle & $\begin{array}{l}\text { Personal } \\
\text { Morality }\end{array}$ & $\begin{array}{c}\text { Company Rules and } \\
\text { Procedure }\end{array}$ & $\begin{array}{c}\text { Laws and } \\
\text { Professional } \\
\text { Codes }\end{array}$ \\
\hline
\end{tabular}

Source: Victor and Cullen $(1987,1988)$

Figure 2. Five Common Empirical Derivatives of Ethical Climate

Locus of Analysis

\begin{tabular}{|c|c|c|c|}
\hline Ethical Theory & Individual & Local & Cosmopolitan \\
\hline Egoism & \multicolumn{2}{|c|}{ Instrument } & \\
\hline Benevolence & \multicolumn{2}{|c|}{ Caring } & \\
\hline Principle & Independence & Rules & $\begin{array}{c}\text { Law and } \\
\text { Code }\end{array}$ \\
\hline
\end{tabular}

Source: Victor and Cullen (1987, 1988), and Neubaum et al. 2004 
related issues, including organizational commitment, job satisfaction, professional commitment, psychological well-being and dysfunctional behaviour. As the focus of the present study is on the effect of the ethical climate on job satisfaction, organizational commitment and professional commitment, the subsequent subsections offer a review of the related literature and the hypotheses to be tested.

\section{Ethical Climate and Organizational and Professional Commitment}

Porter et al. (1974) and Mowday et al. (1979) define organizational commitment as the relative strength of the identification of the individual's involvement with, and attachment to, his/her work organization. In particular, there are three fundamental components of organizational commitment. These are: a strong belief in, and acceptance of, the organization's goals and values (identification); a willingness to exert considerable effort on behalf of the organization (involvement); and a strong intent or desire to remain with the organization (loyalty) (Mowday et al. 1979; Okpara and Wynn 2008). Professional commitment refers to the strength of an individual's identification with a profession. An individual, who is highly committed to the profession, will have a strong belief in, and acceptance of, the profession's goals, a willingness to exert considerable effort on behalf of the profession, and a strong desire to retain membership of the profession (Mowday et al. 1979; Otley and Pierce 1996; Cho and Huang 2012).

Prior studies have discovered that an individual's organizational commitment and professional commitment levels are significantly influenced by the perceived organiza- tional ethical climate (Schwepker 2001; Cullen et al. 2003; Treveno et al. 1998; Okpara and Wynn 2008; Shafer 2009). Studies usually associate higher levels of organizational and professional commitment with the employees' perception of their organization's ethical climate as being caring and principle-based. However, a negative influence of perceived instrumental ethical climate on commitment is often reported. A meta-analytic study by Martin and Cullen (2006) confirmed that caring, independent, rule and professional ethical climates are positively associated with organizational and professional commitment, while an instrumental ethical climate is negatively related to commitment. The fundamental attributes of a caring ethical climate, such as cooperation, mutual personal attraction and positive feelings about tasks, leads to a positive affect towards the organization and profession among its members. Likewise, employees who perceive their organization or profession to have a principle-based ethical climate are likely to be more committed. However, taking into account the collectivism culture whereby decisions are made harmoniously together, rather than individually, and the high power distance among Malaysians, in which subordinates expect to be told what to do, an independent type of ethical climate (i.e. one of the principle-based ethical climate types) may have a negative influence on professional and organizational commitment. Likewise, when employees perceive that the organization or profession approves self-interested attitudes such as cheating, lying and stealing, employees are likely to have less concern about others and thus less attachment to the organization or profession as a whole (Hackman 1992; Wimbush and Shepard 1994; Wech et al. 1998; Martin and Cullen 2006). 
Schwepker (2001), whose study focused on salespeople in the United States, reported a significant relationship between perceived ethical climate and organizational commitment. A study by Cullen et al. (2003) on employees of a telecommunication company and an accounting firm in the United States revealed a positive influence of principle and benevolence-based ethical climate types on employees' commitment to the organizations, and a negative association of a perceived egoistic ethical climate on organizational commitment. Similarly, Treveno et al. (1998), who investigated the relationship between ethical climate and organizational commitment of employees of various industries and occupations in the United States, reported that organizational commitment was higher when the ethical climate of the organization was perceived to be benevolent or principled, but lower when the perceived ethical climate was egoistic. Congruent findings were discovered by Shafer (2009), whose respondents involved auditors in China. The empirical evidence of those earlier studies suggests that employees feel more emotionally attached to organizations that uphold positive values, such as caring, and that adhere to ethical principles, but not with organizations that are perceived as egoistic (Shafer 2009).

In terms of the influence of ethical climate on professional commitment, Shafer (2009), Shafer et al. (2013a and 2013b) and Cho and Huang (2012) admitted that there were a very limited number of studies that investigated the antecedents of professional commitment. A recent study by Shafer et al. (2013b) is among the few studies that have attempted to examine the influence of ethical climate on professional commitment, in addition to organizational commitment. Shafer et al. (2013b), who investigated the moderating effect of professional commit- ment on the relationship between ethical climate and organizational commitment, reported that high professional commitment moderated the association between the benevolent ethical climate type and organizational commitment. Hence, based on the Hofstede theory of culture and findings of prior studies, the following hypotheses $(\mathrm{H})$ were proposed for the current study:

$H_{1 a}$ : The ethical climate types of 'caring,' 'law and code' and 'rules' have significant positive influences on organizational commitment.

$H_{16}$ : The ethical climate types of 'instrumental' and 'independent' bave significant negative influence on organizational commitment.

$H_{2 a}$ : The ethical climate types of 'caring,' 'law and code' and 'rules' have significant positive influences on professional commitment.

$H_{2 b}$ : The ethical climate types of 'instrumental' and 'independent' have significant negative influence on professional commitment.

\section{Ethical Climate and Job Satisfaction}

Job satisfaction refers to the pleasurable or positive emotional state deriving from the overall evaluation of one's job or job experiences (Locke 1976; Shaffer and Harrison 1998; Elci and Alpkan 2008). Based on the fairness-reciprocation argument, employees who consider their organizations as being ethical are also likely to perceive their organizations as being fair to them, and as a result are more likely to reciprocate with a positive attitude and greater job satisfaction. According to Wang and Hsieh (2012), this fairness-reciprocation argument is applicable in comparing employees' perceptions of organizations with different ethical levels, as well as in comparing perceptions of different ethical climate types in an organization. There is 
evidence from prior studies that ethical climate perceptions influence job satisfaction (Deshpande 1996; Joseph and Deshpande 1997; Koh and Boo 2001; Schwepkers 2001; Tsai and Huang 2008). Meta-analytic studies by Parker et al. (2003), and Martin and Cullen (2006) also suggested that a strong relationship exists between the perceived organizational ethical climate and employees' work outcome, which includes job satisfaction.

A study by Deshpande (1996) on managers of a nonprofit organization in the United States discovered a significant positive effect of professional and caring ethical climate on job satisfaction and a significant negative influence of an instrumental ethical climate type on job satisfaction. Another study on managers in Singapore by Koh and Boo (2001) revealed that the principle ethical climate perceptions were positively related to job satisfaction. Joseph and Deshpande (1997) studied the relationship between ethical climate types and job satisfaction among nurses in a U.S. hospital. The study reported that caring and rules ethical climates resulted in a higher job satisfaction. Tsai and Huang (2008), who examined the relationship between the perceived ethical climate types and job satisfaction of nurses in Taiwan, revealed that the caring, independent and rules ethical climate had a positive effect on job satisfaction. Comparable results were reported by Wang and Hseih (2012), who studied the employees of various industries in Taiwan. A study by Kim and Miller (2008) of employees of large tourism companies in Korea found that the perceived law-and-code ethical climate type had a positive influence on job satisfaction. Similar results for the positive association between law-and-code ethical climate type perceptions and job satisfaction were also discovered by Elci and Alpkan (2009), whose sample comprised of employ- ees of telecommunication companies in Turkey.

This review of related prior studies clearly reveals a paucity of research examining the influence of ethical climate type perceptions on job satisfaction in the accounting profession (i.e. auditors) in the context of a developing country such as Malaysia. Evidence from the little research that has been published suggests that the independent, caring, law and code and rules ethical climate types have a positive impact on job satisfaction, whilst an instrumental ethical climate has a negative significant association. However, the unique culture of high power distance and collectivism among Malaysians, being independent in making ethical decision (i.e. each person in the firm decides for him/ herself what is right and wrong), may not lead to favorable satisfaction among employees towards their job. In light of the existing published research and based on the fairness-reciprocation argument and Hofstede's theory of culture, the following hypotheses are proposed:

$H_{3 a}$ : The ethical climate types of 'caring,' 'law and code' and 'rules' have significant positive influence on job satisfaction.

$H_{3 b}$ : The ethical climate types of 'instrumental' and 'independent' have significant negative influence on job satisfaction.

\section{Methods}

\section{Sample}

The sample group for this study consisted of auditors working with audit firms registered with the Malaysian Institute of Accountants (MIA). The process of the distribution of the questionnaire was assisted by students selected from the researcher's 
institution who were undergoing an internship program with the registered audit firms in the sample. The list of firms was obtained from the researcher's university database, which comprises of firms that accept accounting degree students for internship. The database listed 82 audit firms with trainees currently undergoing their internship. Depending on the size of the firms, three to ten questionnaires were sent to each firm. A total of 350 questionnaires were distributed. Each potential respondent received a cover letter explaining the purpose of the study, which also assured confidentiality, and included a copy of the questionnaire. The questionnaire took an average of 15 to $20 \mathrm{~min}$ utes to complete. Two weeks after the distribution of the cover letter and questionnaires, the students helped collect the completed forms from the respondents and submitted them to the researchers. A total of 263 respondents returned the completed questionnaires, representing a usable response rate of approximately 75.1 percent.

\section{Measures}

A survey questionnaire comprising of demographic information and measures of the ethical climate, job satisfaction, organizational commitment and professional commitment was used to elicit data for the present study.

Ethical Climate. This study employed a 26-item scale of five types of ethical climates outlined by Victor and Cullen (1987, 1988). Respondents were requested to indicate on a seven-point Likert scale (1= strongly disagree, $7=$ strongly agree) the extent to which they disagreed or agreed with each of the items that described the general ethical climate of their firm. The Cronbach's alphas for the five types of ethical climates ranged from 0.72 to 0.84 .
Job Satisfaction. Dubinsky and Hartley's (1986) job satisfaction scale was adopted in this study. The scale consisted of 5 items: 'Generally speaking, I am very satisfied with this job;' 'I frequently think of quitting this job;' 'I am generally satisfied with the kind of work I do in this job;' 'Most people on this job are very satisfied with the job;' and 'People on this job often think of quitting.' The auditors were requested to indicate their level of agreement with each of the items on a seven point agree-disagree scale. Two of the items were reversely coded before carrying out the data analysis. The higher score reflects greater satisfaction with the present job. Cranbach's alpha for job satisfaction was 0.81 .

Organizational Commitment. A four-item scale of organizational commitment developed by Hunt et al. (1989) was used in this study. The items included: 'I would not be willing to change firms even if the new job offered a 25 percent pay increase;' 'I would be willing to change firms if the new job offered more creative freedom;' 'I would be willing to change firms if the new job offered more status;' 'I would be willing to change firms if the new job was with people who were more friendly.' The items were measured on a seven-point Likert scale ranging from 1, being 'strongly disagree,' to 7, being 'strongly agree.' Before undertaking our analysis, the first item of the instrument was reversely recoded to ensure consistency in the measurement of all the items. A higher score for the organizational commitment scale reflects a lower commitment of auditors to the firm that they are currently attached to. Cronbach's alpha for this scale was 0.76 .

Professional Commitment. A fiveitem scale of professional commitment outlined by Blau (1999) was used in this study. The five items were: 'If I could get another 
job other than being an accountant, and get paid the same amount of money, I would probably take it;' 'I definitely want a career for myself in accounting;' 'If I could do it all over again, I would choose to work in the accounting profession;' 'I would recommend a career in accounting to others;' and 'I am disappointed that I ever entered the accounting profession.' Respondents were requested to indicate on a seven-point Likert scale (1= strongly disagree, $7=$ strongly agree) the extent to which they disagreed or agreed with each of the items. Items one and five were inversely coded and, therefore, a higher score indicates a greater commitment by the auditors to the accounting profession. The Cronbach's alphas for the items was 0.67.

\section{Data Analysis}

The data were analyzed using the Statistical Package for the Social Sciences (SPSS) software. Basically, the descriptive statistics consist of frequency distributions, and percentages were tabulated to develop demographic profiles of auditors in Malaysia. In addition, a descriptive analysis of the mean score and standard deviation was computed for the Likert-scale questions, including the organizational commitment, professional commitment, job satisfaction and the five ethical climate types. In testing the hypotheses, both Pearson's zero correlation and multiple regression analysis were carried out. While correlation provides only an estimate of the association between variables, regression analysis reveals the dependence of a variable on other explanatory variables. In other words, regression analysis provides more valid and reliable results. There were three multiple regression models developed. In each model, the mean score of the organizational commitment, professional commit- ment and job satisfaction respectively was the dependent variable, while the independent variables were the five ethical climate types, namely professional, caring, rules, instrumental and independence. Gender and length of related work experience were the control variables. The three relevant models were as follows:

\section{Model 1:}

Organizational commitment $=$

$$
\begin{aligned}
& \alpha+\beta_{1} \text { PROFESIONAL }+\beta_{2} \text { CARING } \\
& +\beta_{3} \text { RULES }+\beta_{4} \text { INSTRUMENTAL } \\
& +\beta_{5} \text { INDEPENDENCE }+\beta_{6} \text { GENDER } \\
& +\beta_{7} \text { WORKEXPERIENCE }+\varepsilon
\end{aligned}
$$

\section{Model 2:}

Professional commitment $=$

$\alpha+\beta_{1}$ PROFESIONAL $+\beta_{2}$ CARING

$+\beta_{3}$ RULES $+\beta_{4}$ INSTRUMENTAL

$+\beta_{5}$ INDEPENDENCE $+\beta_{6}$ GENDER

$+\beta_{7}$ WORKEXPERIENCE $+\varepsilon$

\section{Model 3:}

Job satisfaction $=$

$$
\begin{aligned}
& \alpha+\beta_{1} \text { PROFESIONAL }+\beta_{2} \text { CARING } \\
& +\beta_{3} \text { RULES }+\beta_{4} \text { INSTRUMENTAL } \\
& +\beta_{5} \text { INDEPENDENCE }+\beta_{6} \text { GENDER } \\
& +\beta_{7} \text { WORKEXPERIENCE }+\varepsilon
\end{aligned}
$$

\section{Findings and Discussion}

Table 1 depicts the demographic information of the respondents of this study and the descriptive statistics of mean and standard deviations for all variables. 62.7 per cent of the respondents were females. Slightly more than half of the responding auditors were within the age range of 20 to 29 years old, and had more than five years' work ex- 
Table 1. Demographic Data and Descriptive Statistics

\begin{tabular}{lrc}
\hline & Frequency & Percentage \\
\hline Gender & & \\
Male & 98 & 37.3 \\
Female & 165 & 62.7 \\
Total & 263 & 100 \\
& & \\
Age & & \\
Less than 20 years & 3 & 1.1 \\
20-29 years & 137 & 52.1 \\
30-39 years & 82 & 31.2 \\
40-49 years & 33 & 12.5 \\
50-60 years & 33 & 1.1 \\
Total & 263 & 100 \\
& & \\
Working Experience & & \\
in Accounting Field & & \\
Less than 5 years & 113 & 43.0 \\
5-10 years & 101 & 38.4 \\
11-15 years & 32 & 12.2 \\
15-20 years & 10 & 3.8 \\
More than 20 years & 7 & 2.7 \\
Total & 263 & 100 \\
& & \\
\hline
\end{tabular}

perience. The responding auditors were in various positions.

The mean value for job satisfaction of 5.04 indicates that the sampled auditors are generally satisfied with their current job. The means for organizational commitment and professional commitment of 2.68 and 4.97 respectively show that the auditors are not quite so committed to the firms that they are currently working for, but are reasonably committed to their profession as auditors. In relation to the ethical climate types, the highest mean score among the five types of ethical climate was 5.13 for professional climate, which indicates that the auditors perceived this type of ethical climate in their organizations to be highly satisfactory.

\begin{tabular}{lrc}
\hline & Frequency & Percentage \\
\hline Current Position & & \\
Associate & 105 & 39.9 \\
Senior Associate & 87 & 33.1 \\
Assistant Manager & 23 & 8.7 \\
Manager & 27 & 10.3 \\
Senior Manager & 10 & 3.8 \\
Partner & 11 & 4.2 \\
Total & 263 & 100 \\
& & \\
& Mean & SD \\
Organizational commitment & 2.47 & 0.73 \\
Professional commitment & 5.00 & 1.03 \\
Job satisfaction & 5.04 & 1.11 \\
Professional climate & 4.92 & 0.81 \\
Caring climate & 4.80 & 0.75 \\
Rules climate & 4.83 & 0.85 \\
Instrumental climate & 4.30 & 0.76 \\
Independence climate & 4.12 & 0.94 \\
& & \\
\hline
\end{tabular}

Table 2 and Table 3 provide the results of the Pearson's zero correlation and the multiple regression analysis respectively. Consistent results were revealed by the two analyses as depicted in the two tables. The caring ethical climate had a positive significant relationship with the organizational commitment of auditors, while the instrumental and independent ethical climate types had a negative significant association with organizational commitment. The results suggest that the greater the perceived caring ethical climate type, the higher the commitment of the auditors was to the firm. On the other hand, a lower commitment to the organization was associated with greater perceptions of instrumental and independent ethical climate types. The remaining two types of ethical climate 
Table 2. Pearson's Zero-order Correlations for All Variables

\begin{tabular}{|c|c|c|c|c|c|c|c|c|c|}
\hline \multicolumn{10}{|c|}{ Panel1 } \\
\hline \multirow[b]{2}{*}{1} & \multirow[b]{2}{*}{ Organizational commitment } & \multirow{2}{*}{$\begin{array}{l}1 \\
1 \\
1\end{array}$} & \multirow[t]{2}{*}{2} & \multirow[t]{2}{*}{3} & \multirow[t]{2}{*}{4} & \multirow[t]{2}{*}{5} & \multirow[t]{2}{*}{6} & \multirow[t]{2}{*}{7} & \multirow[t]{2}{*}{8} \\
\hline & & & & & & & & & \\
\hline 2 & Law and code climate & 0.11 & 1 & & & & & & \\
\hline 3 & Caring climate & $0.21 * * *$ & $0.41 * * *$ & 1 & & & & & \\
\hline 4 & Rules climate & 0.08 & $0.44^{* * *}$ & $0.49 * * *$ & 1 & & & & \\
\hline 5 & Instrumental climate & $-0.19 * *$ & $0.35^{* * *}$ & $0.38^{* * *}$ & $0.39 * * *$ & 1 & & & \\
\hline 6 & Independence climate & $-0.17 * *$ & $0.16^{* *}$ & $0.40^{* * *}$ & $0.16^{* *}$ & $0.50 * * *$ & 1 & & \\
\hline 7 & Gender & 0.09 & -0.11 & $-0.14 *$ & $-0.19 * *$ & -0.09 & -0.07 & 1 & \\
\hline 8 & Length of experience & -0.09 & 0.09 & $0.27 * * *$ & $0.21^{* * *}$ & 0.05 & 0.06 & -0.11 & 1 \\
\hline
\end{tabular}

\section{Panel2}

1 Professional commitment

1

2 Law and code climate

$0.23^{* * *} \quad 1$

3 Caring climate

$0.21 * * * \quad 0.41 * * * \quad 1$

4 Rules climate

0.12

$0.44 * * *$

$0.49 * * *$

$0.110 .35^{* * *}$

$0.38^{* * *}$

1

5 Instrumental climate

$-0.18^{* *}$

$0.16^{* *}$

$0.40 * * *$

$0.39 * * * \quad 1$

6 Independence climate

0.04

$-0.11$

$-0.14 *$

$0.16^{* *} \quad 0.50^{* * *}$

7 Gender

$0.19 * *$

$0.09 \quad 0.27 * * *$

$-0.19 * * \quad-0.09$

$-0.07 \quad 1$

8 Length of experience

\section{Pane13}

1 Job satisfaction

1

2 Law and code climate

$0.1 \quad 1$

3 Caring climate

$0.39 * * *$

$0.41 * * *$

$-0.12^{*}$

$0.44 * * *$

1

4 Rules climate

$-0.21 * * *$

$0.35^{* * *}$

$0.49 * * *$

$0.21 * * *$

0.05

$\begin{array}{lll}0.06 & -0.11 \quad 1\end{array}$

5 Instrumental climate

6 Independence climate

0.08

$0.16^{* *}$

$0.38^{* * *}$

1

7 Gender

$-0.01$

$-0.11$

$0.40 * * *$

$0.39 * * * \quad 1$

8 Length of experience

0.1

$0.09 \quad 0.27 * * *$

$0.16^{* *} \quad 0.50^{* * *} \quad 1$

$\begin{array}{llll}-0.19 * * & -0.09 & -0.07 & 1\end{array}$

$\begin{array}{lllll}0.21^{* * *} & 0.05 & 0.06 & -0.11 & 1\end{array}$

${ }^{* * *} \mathrm{p}<0.001,{ }^{* *} \mathrm{p}<0.05$ 
Table 3. Regression Results

\begin{tabular}{|c|c|c|c|c|c|c|}
\hline \multirow{4}{*}{$\begin{array}{l}\text { Dependent variable } \\
\text { Law and code climate }\end{array}$} & \multicolumn{2}{|c|}{ Model1 } & \multicolumn{2}{|c|}{ Model 2} & \multicolumn{2}{|c|}{ Model 3} \\
\hline & Beta & $\mathbf{t}$ & Beta & $\mathbf{T}$ & Beta & $\mathbf{T}$ \\
\hline & \multicolumn{2}{|c|}{$\begin{array}{c}\text { Organizational } \\
\text { commitment }\end{array}$} & \multicolumn{2}{|c|}{$\begin{array}{l}\text { Professional } \\
\text { commitment }\end{array}$} & \multicolumn{2}{|c|}{ Jobsatisfaction } \\
\hline & -0.16 & -1.08 & 0.33 & $1.26^{* * *}$ & 0.05 & 0.36 \\
\hline Caring climate & 0.43 & $2.77 * * *$ & 0.29 & $1.88^{* * *}$ & 0.84 & $4.95^{* * *}$ \\
\hline Rules climate & 0.15 & 0.77 & -0.13 & -1.11 & -0.32 & $-1.81 *$ \\
\hline Instrumental climate & -0.23 & $-1.53^{* *}$ & -0.04 & -0.02 & -0.46 & $-2.66 * * *$ \\
\hline Independence climate & -0.28 & $-1.33^{* *}$ & -0.2 & $-1.76^{* *}$ & -0.13 & 1.81 \\
\hline \multicolumn{7}{|l|}{ Control variables } \\
\hline Gender & 0.1 & 0.55 & -0.08 & -0.43 & 0.05 & 0.22 \\
\hline Work experience & 0.01 & 0.05 & 0.21 & $2.22^{* *}$ & 0.13 & 1.19 \\
\hline $\mathrm{R} 2$ & \multicolumn{2}{|c|}{0.11} & \multicolumn{2}{|c|}{0.14} & \multicolumn{2}{|c|}{0.25} \\
\hline Adjusted R2 & \multicolumn{2}{|c|}{0.09} & \multicolumn{2}{|c|}{0.1} & \multicolumn{2}{|c|}{0.21} \\
\hline $\mathrm{N}$ & \multicolumn{2}{|c|}{263} & \multicolumn{2}{|c|}{263} & \multicolumn{2}{|c|}{263} \\
\hline
\end{tabular}

${ }^{* * *} \mathrm{p}<0.001,{ }^{* *} \mathrm{p}<0.05$

(law and code and rules) did not significantly associate with organizational commitment. The findings on the positive and negative relationships between caring and instrumental ethical climate types and organizational commitment are consistent to prior studies, including those of Treveno et al. (1998), Cullen et al. (2003), Shafer (2009) and Shafer et al. (2013b). The results therefore fully support $H_{1 b}$, but do not support $H_{1 a^{\circ}}$

While caring and law and code climate types had a positive significant relationship with professional commitment, the independent ethical climate type was negatively significant. Therefore, $H_{2 a}$ and $H_{2 b}$ are not supported. The findings implied that the greater the perceived caring and law and code ethical climate types in the organization, the more committed the auditors were to their profession. This finding is consistent with the result from Shafer et al. (2013b). By contrast, the higher the perceived independent ethical climate, the lower the commitment of the auditors was to the profession.

The result of the significant negative relationship between an independent ethical climate type and organizational and professional commitments, although contradicting evidence reported by most prior studies, is unique in the context of the current study. This may well be explained by the cultural differences of the respondents from a developing country, as explained by the Hofstede's theory of culture. The collectivism and high power distance culture among Malaysians, whereby decisions are not normally made on 
individual basis, and only by those with greater authority, may have contributed to the adverse impact of an independence ethical climate (each person in the firm decides for $\mathrm{him} /$ herself what is right and wrong) on commitments.

In terms of the effect of the ethical climate types on job satisfaction, there was evidence that job satisfaction is positively associated with the caring ethical climate type but is negatively associated with instrumental and rules climate types. The results indicated that the more auditors perceive the ethical climate of their organization to be caring and the less they perceive it as instrumental and rule based, the more satisfied they are with their work. The results therefore to some extent support $H_{3 a}$ and $H_{3 b}$. The results are in line with evidence reported in prior studies such as those of Deshpande (1996), Joseph and Deshpande (1997), Martin and Cullen (2006), Tsai and Huang (2008) and Wang and Hseih (2012).

\section{Implications, Limitations and Suggestions for Future Research}

The present study investigated the influence of ethical climate types on the three work-related outcomes of organizational commitment, professional commitment and job satisfaction among auditors in Malaysia. The study discovered a significant positive association between a caring ethical climate type and all three work outcomes. A positive significant relationship was also revealed between a professional ethical climate type and professional commitment. In addition, the study found a significant negative relationship between an instrumental ethical climate type and both organizational commitment and job satisfaction. Interestingly, in contrast to the findings of prior studies, the current study reported that an independent ethical climate type negatively associated with organizational and professional commitment, as well as the job satisfaction of auditors in Malaysia.

The evidence related to the different effects of ethical climate type on auditors' work outcomes, in terms of commitment to the audit firm as well as the accounting profession and satisfaction with audit work, provides vital information to the accounting regulatory body, audit firms, auditors and other interested parties. In facilitating the Malaysian government's goal of an increased number of accountants, including auditors, The Malaysian Institute of Accountants (MIA) (i.e. the accounting regulatory body in Malaysia) may want to promote the importance of having a caring and professional ethical climate and to encourage audit firms registered with MIA to foster these ethical climate types in their firms, in order to ensure auditors have better commitment to the firm and the profession and greater satisfaction in performing their tasks as auditors. This could minimize the turnover rate among Malaysian auditors. Promotion and encouragement of the appropriate ethical climate types among audit firms can be carried out by the MIA as part of their training and seminar programs.

For audit firms, acquiring a thorough understanding of the concept of various ethical climate types is necessary in order to nurture appropriate ethical climate types (such as caring and professional climate types) within their organizations. This could be achieved through education, by having managers attend relevant training courses and seminars, and by learning from other firms which have established positive cultures in their organizations. On the part of the auditors, the fundamental message from the cur- 
rent findings is for them to consider attaching themselves to firms that adopt appropriate ethical climate types so that they will be satisfied when carrying out their job and will be committed to their profession as well as the firm. In this way auditors can make more informed choices as they plan their career advancement.

The unique finding of the present study of the discouraging influence of an independent ethical climate type (individuals in the firm decide for themselves what is right and wrong) on both organizational and professional commitment contributes to the theory of cultural dimensions as the findings suggest that cultural factors specific to the Malaysian context may be operating. Specifically, reference to Hofstede's cultural dimensions of collectivist and individualism is useful. As a collectivist culture, Malaysia values and supports a strong connection among individuals in the community, which promotes conformity (Hofstede 1980). This is in contrast to the individualistic culture in developed Western countries (Hofstede 1980). In the case of the relationship between independent ethical climate types and Malaysian auditors' organizational and professional attachment, the evidence shows that an independent ethical climate type within an organization is not conducive to retaining auditors, and is therefore to be discouraged.

This present study is not without its limitations. The first limitation is in terms of the direct adoption of the five types of ethical climate types and the questionnaire items for each type, which may not provide the most accurate ethical climate types for the sample under study. Future researchers could carry out factor analysis before deciding on the valid items for each ethical climate type and also on the number of ethical climate types existing within the sample of the study.
The second limitation of this present study is that it examined mainly the direct effect of ethical climate types on each of the three work outcomes: organizational commitment, professional commitment and job satisfaction. As there could also be indirect effects between variables, future studies may want to consider investigating the mediating and/ or moderating effects of certain variables such as professional commitment on each work outcome. There could also be a relationship between work outcomes such as the influence of organizational commitment on job satisfaction, which is worth investigating in future research in order to better understand the issues under study. Future studies could also include a variable on the auditors' rate of turnover in order to directly and better delve into the issue of high turnover among auditors.

A further limitation is that the present study covers only one group of respondents -private sector external auditors. Future studies could include different groups of respondents, such as internal auditors and public sector auditors for comparison purposes in order to better understand the influence of ethical work climate types on various workrelated outcomes. To some extent, it is also a limitation of the current study, in that it focused on a single dimension of organizational commitment. To get a better insight into the influence of ethical climate types on organizational commitment, it is suggested that future studies consider the multidimensional constructs of organizational commitment. It is also acknowledged that the findings of the present study may have been to some extent affected by the common method bias problem, as both the dependent and the independent variables were obtained from a single source. However, in mitigating the potential impact of the common method bias on the 
results of the present study, Harman's single factor test was used and the results showed that the instrument items did not belong to only one factor, which to some extent indicates that the common method is not a major problem in the present study (Podsakoff et al. 2003). Moreover, the common method variance issue was further assessed using the correlation matrix (Bagozzi et al. 1999). Correlation results as shown in Table 2 , show no value of more than 0.9 , an indication of no common method bias problem existing.
Despite its limitations, the present study offers a number of insights concerning the influence of the ethical work climate on work outcomes in the Malaysian context. The results contribute to the body of empirical evidence on the ethical culture types that promote the organizational commitment, professional commitment and job satisfaction of auditors. In this way the study addresses, at least indirectly, the worrying problem of high staff turnover and the Malaysian Institute of Accounting's aspiration to attract and retain auditors.

\section{References}

Bagozzi, R. P., Y. Yi, and L. W. Phillips. 1991. Assessing construct validity in organizational research. Administrative Science Quarterly 36 (3) (September): 421-458.

Blau, G. 1999. Early-career job factors influencing the professional commitment of medical technologists. Academy of Management Journal 42 (6): 687-695.

Cho, V., and X. Huang. 2012. Professional commitment, organizational commitment, and the intention to leave for professional advancement: An empirical study on IT professionals. Information Technology and People 25 (1): 31-54.

Cotton, J., and J. Tuttle. 1986. Employee turnover: A meta-analysis and review with implications for research. Academy of Management Review 11 (1): 55-70.

Cullen, J. B., K. P. Parboteeah, and B. Victor. 2003. The effects of ethical climates on organizational commitment: A two-study analysis. Journal of Business Ethics 46 (2): 127-141.

Deshpande, S. P. 1996. The impact of ethical climate types on facets of job satisfaction: An empirical investigation. Journal of Business Ethics 15 (6): 655-660.

Dubinsky, A. J., and S. W. Hartley. 1986. A path-analytic study of a model of salesperson performance. Journal of the Academy of Marketing Science 14 (1): 36-46.

Economist. 2007. Accounting for Good People. Available at: http://www.cfo.com/article.cfm/9531108/ c_9826993 (Accessed on 21 August 2014).

Elçi, M., and L. Alpkan. 2009. The impact of perceived organizational ethical climate on work satisfaction. Journal of Business Ethics 84 (3): 297-311.

Hartikainen, O., and S. Torstila. 2004. Job-related ethical judgment in the finance profession. Journal of Applied Finance 14: 62-76.

Ho, F. N., S. J. Vitell, J. H. Barnes, and R. Desborde. 1997. Ethical correlates of role conflict and ambiguity in marketing: The mediating role of cognitive moral development. Journal of the Academy of Marketing Science 25 (2): 117-126.

Hofstede, G. 1980. Culture's Consequences: International Differences in Work-Related Values. Newbury Park: Sage. 
Hunt, S. D., V. R. Wood, and L. B. Chonko. 1989. Corporate ethical values and organizational commitment in marketing. The Journal of Marketing: 79-90.

Joseph, J., and S. P. Deshpande. 1997. The impact of ethical climate on job satisfaction of nurses. Health Care Management Review 22 (1): 76-81.

Kim, N. Y., and G. Miller. 2008. Perceptions of the ethical climate in the Korean tourism industry. Journal of Business Ethics 82 (4): 941-954.

Koh, H. C., and E. H. Y. Boo. 2001. The link between organizational ethics and job satisfaction: A study of managers in Singapore. Journal of Business Ethics 29: 30924.

Lee, T. H., and M. A. Azham. 2009. Audit challenges in Malaysia today. Accountants Today (October).

Locke, E. A. 1976. The Nature and Causes of Job Satisfaction1. Hand book.

Malaysian Accountancy Research and Education Foundation (MAREF). 2012. Stress at work amongst auditors: is there a light at the end of the tunnel. MAREF Review 1 (2): 1-3.

Martin, K. D., and J. B. Cullen. 2006. Continuities and extensions of ethical climate theory: A meta-analytic review. Journal of Business Ethics 69 (2): 175-194.

McHoskey, J. W. 1996. Authoritarianism and ethical ideology. The Journal of Social Psychology 136 (6): 709 717.

Mowday, R. T., R. M. Steers, and L. W. Porter. 1979. The measurement of organizational commitment. Journal of Vocational Behavior 14 (2): 224-247.

New Straits Times. 2014. 'Wanted: More accountant, Available at: http://www.nst.com.my/node/26650 (Accessed on 21 September).

Okpara, J. O., and P. Wynn. 2008. The impact of ethical climate on job satisfaction, and commitment in Nigeria: Implications for management development. Journal of Management Development 27 (9): 935 950.

Otley, D. T., and B. J. Pierce. 1996. The operation of control systems in large audit firms. Auditing 15: 6584.

Parker, C. P., B. B. Baltes, S. A. Young, J. W. Huff, R. A. Altmann, H. A. Lacost, and I. E. Roberts. 2003. Relationships between psychological climate perceptions and work outcomes: a meta analytic review. Journal of Organizational Behavior 24 (4): 389-416.

Porter, L. W., R. M. Steers, R. T. Mowday, and P. V. Boulian. 1974. Organizational commitment, job satisfaction, and turnover among psychiatric technicians. Journal of Applied Psychology 59 (5): 603.

Schwepker Jr, C. H. 2001. Ethical climate's relationship to job satisfaction, organizational commitment, and turnover intention in the salesforce. Journal of Business Research 54 (1): 39-52.

Shafer, W. E. 2008. Ethical climate in Chinese CPA firms. Accounting, Organizations and Society 33 (7): 825835.

Shafer, W. E. 2009. Ethical climate, organizational-professional conflict and organizational commitment: a study of Chinese auditors. Accounting, Auditing and Accountability Journal 22 (7):1087-1110.

Shafer, W. E., M. C. Poon, and D. Tjosvold. 2013a. Ethical climate, goal interdependence, and commitment among Asian auditors. Managerial Auditing Journal 28 (3): 217-244.

Shafer, W. E., M. C. Poon, and D. Tjosvold. 2013b. An investigation of ethical climate in a Singaporean accounting firm. Accounting, Auditing and Accountability Journal 26 (2):312-343. 
Shaffer, M. A., and D. A. Harrison. 1998. Expatriates' psychological withdrawal from international assignments: Work, nonwork, and family influences. Personnel Psychology 51 (1): 87-118.

Singhapakdi, A., M. Y. Rawwas, J. K. Marta, and M. I. Ahmed. 1999. A cross-cultural study of consumer perceptions about marketing ethics. Journal of Consumer Marketing 16 (3):257-272.

Singhapakdi, A., S. J. Vitell, and O. Leelakulthanit. 1994. A cross-cultural study of moral philosophies, ethical perceptions and judgements: A comparison of American and Thai marketers. International Marketing Review 11 (6): 65-78.

The Star. 2013. More Accountants Needed: Says MLA Chief. Available at: http:/ /www.thestar.com.my/Business/Business-News/2013/09/17/More-accountants-needed-says-MIA-chief.aspx/ (Accessed on 21 August 2014).

Trevino, L. K., K. D. Butterfield and D. L. McCabe. 1998. The ethical context in organizations: Influence on employee attitudes and behaviors. Business Ethics Quarterly 8: 447-476.

Tsai, M. T., and C. C. Huang. 2008. The relationship among ethical climate types, facets of job satisfaction, and the three components of organizational commitment: A study of nurses in Taiwan. Journal of Business Ethics 80 (3): 565-581.

Victor, B., and J. B. Cullen. 1987. A theory and measure of ethical climate in organizations. Research in Corporate Social Performance and Policy 9.

Victor, B., and J. B. Cullen. 1988. The organizational bases of ethical work climates. Administrative Science Quarterly: 101-125.

Wang, Y. D., and H. H. Hsieh. 2012. Toward a better understanding of the link between ethical climate and job satisfaction: a multilevel analysis. Journal of Business Ethics 105 (4): 535-545. 